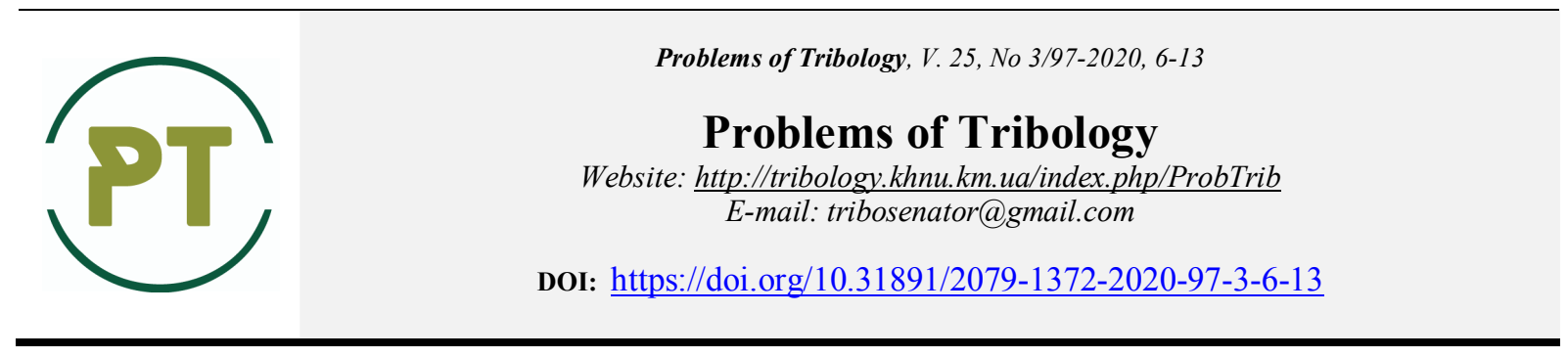

\title{
The determination of the information frequencies in the frame of the acoustic emission signals from the friction zone of tribosystems
}

\author{
K.A. Fenenko \\ Kharkov National Technical University of Agriculture named after Petro Vasylenko, Kharkov, Ukraine \\ E-mail:vavoitovva@gmail.com
}

\begin{abstract}
Based on the analysis of the works devoted to the selection of informative AE parameters for the diagnosis of tribosystems, in a theoretical way the information frequency ranges in the AE signal frame, where the maximum amplitudes values are observed, have been established. It has been theoretically and experimentally established that the information frequencies depend on the following groups of factors: the constructive; technological and operational ones. The degree of influence of the factors on the change in the frequency range is established. The operational factors (slip speed and load) change the frequency range from 106 to $584 \mathrm{kHz}$, the technological factors (roughness of the friction surfaces) change the frequency range from 118 to $618 \mathrm{kHz}$, the constructive factors (the size of the friction area of the stationary triboelement) change the frequency range from 140 to $530 \mathrm{kHz}$. It has been concluded that for the effective diagnosis of tribosystems, it is necessary to previously determine the information frequency range taking into account the factors listed above.

The obtained results were confirmed experimentally with the calculation of the Fisher and Cochrane criteria, which allows one to state about the presence of a correlation between the theoretical values of the information frequencies generated by the tribosystem and the experimental values of the frequencies, where the maximum amplitudes were recorded, the correlation coefficient $r=0,88$.

The present analysis can be the basis for the development of a diagnostic method for tribosystems during their operation, which will increase the robustness and information content of the AE method.
\end{abstract}

Key words: tribosystem; information frequencies; acoustic emission; frequency range; diagnosis; constructive, technological, operational factors.

\section{Introduction}

One of the most effective methods for diagnosing tribosystems is the method of acoustic emission (AE). Acoustic vibrations during friction are generated by the impact interaction of roughnesses and elastoplastic deformation of the mating surfaces, the processes of friction bonds fracture and structural-phase reconstruction of materials, the formation and development of cracks in the surface layers of the interacting bodies, and the separation of wear particles [1,2]. As it is known, the frictional interaction of two bodies does not occur over the entire area of the contacting surfaces, but within the "actual contact spots". Due to the discrete nature of the frictional contact of solid bodies, as well as the random nature of the distribution of the temperature and deformation fields on the spots of the actual contact, friction and wear are of a statistical nature.

At present, acoustic emission is actually understood as a secondary process, which is a superposition of signals from a huge number of elementary sources of $\mathrm{AE}$, i.e. $\mathrm{AE}$ is the result of collective processes of structural units (the defects in the structure of the material). Moreover, it is believed that this secondary process is the result of the interference of primary acoustic waves that satisfy the coherence condition $[3,4]$.

\section{Literature review}

In work [5], the frequency component of the AE signal from the friction zone was analysed. The author has found out that the AE signals, generated by the friction pair, correspond to a frequency of over $30 \mathrm{kHz}$. It is this value that is made up by the lower cut-off frequency of the filters of the high-pass filters of the equipment. 
Studying the experimental graphs of the amplitude-frequency characteristics of the AE signals in the range of $30 \mathrm{kHz} \ldots 1 \mathrm{MHz}$, the author has found out that the maximum values of the amplitudes are in the frequency range of $80 \ldots 100 \mathrm{kHz}$.

The authors of [6] have found out that the AE signal from the friction zone has two characteristic types of frames, each of which has its own sources. The first of them is characterized by an increase in the median frequency and amplitude in the region of $80 \ldots 240 \mathrm{kHz}$ and is typical for the separation of wear particles. The second is typical for the frequencies of $30 \ldots 40 \mathrm{kHz}$ without amplitude spikes and is typical for an intense and non-stationary plastic deformation.

In works [7-9], the frequency component of the AE signal of various alloys was analysed during plastic deformation. The authors have established the following frequency ranges in which the maximum amplitudes values are manifested: plastic deformation $50 \ldots 200 \mathrm{kHz}$; twinning processes $200 \ldots 500 \mathrm{kHz}$; martensitic transformations $250 \ldots 400 \mathrm{kHz}$; crack jumps $250 \ldots 600 \mathrm{kHz}$. The authors conclude that the maximum signal amplitudes are typical for twinning processes and jump-like growth of cracks.

In works [10 - 14], a correlation was established between the activity of acoustic emission and the deformation rate. The authors conclude that when examining the flow of acoustic signals during plastic deformation, it is possible to limit the upper frequency bound by $400 \ldots 600 \mathrm{kHz}$. The data presented in the works indicate that the signal amplitude can characterize the density of non-random, interdependent elementary deformation events during plastic deformation of metallic materials and correlates with the deformation rate, dimension $1 / \mathrm{s}$.

Based on the analysis of the works devoted to the selection of the informative parameters of AE for the diagnosis of tribosystems, we can conclude that to increase the robustness of the method, the most promising approach may be the selection of the informative frequency ranges in the AE signal frame and the determination of the signal peak factor in this frequency range. Such an approach will allow getting information on a separate group of processes occurring in the surface layers of the materials of the tribosystem, which will increase the robustness of this method and the informational content of diagnosing tribosystems.

\section{Purpose}

The aim of this study is to determine the information frequency range for analysing the frame of the AE signals from the friction zone of the tribosystem with the establishment of a correlation with the constructive, technological and operational factors, which will allow diagnosing the processes of friction and wear.

\section{Methods}

To justify the choice of the information frequency range for the analysis of the AE signal frame from the friction zone of the tribosystem with the division of the signal into groups of the sources of its generation, let us use the main conclusions of the above analysis of the works.

1. The activity of acoustic emission during the operation of the tribosystem will depend on the rate of deformation of the materials on the spots of the actual contact, dimension $1 / \mathrm{s}$.

2. The total acoustic signal from the friction zone is formed as a result of interference of the primary acoustic signals from the spots of the actual contact with the friction surface, which satisfy the coherence condition [10 - 14]. The sources of the acoustic signal have been substantiated in works $[5,6]$.

Based on these conditions and limitations, one can write an expression for calculating the information frequency that will be generated by the tribosystem during operation:

$$
f_{A E}=n \dot{\varepsilon}(1+\mu)(1-2 \mu), 1 / \mathrm{s},
$$

where $f_{A E}$ - the information frequency of the AE signals from the friction zone, dimension $1 / \mathrm{s}$; of friction;

$n-$ is the total number of the contact spots on the friction surface of the triboelement with a smaller area

$\dot{\varepsilon}-$ is the value of the deformation rate on a single spot of the actual contact, dimension $1 / \mathrm{s}$;

$\mu-$ is the Poisson's ratio.

The number of contact spots $n$ on the smaller friction surface of one of the triboelements $F_{\min }$ will be determined by the expression:

$$
n=\frac{F_{\min }}{A_{c}} \eta
$$

where $F_{\min }$ - is the friction area of the triboelement, which has a smaller working surface, dimension $\mathrm{m}^{2}$;

$\eta-$ is the relative actual contact area, determined by the formulas that are given in work [15], dimensionless quantity; 
$A_{c}$ - is the average area of a single actual contact spot, determined by the formulas that are given in work [15], dimension $\mathrm{m}^{2}$

The deformation rate of the material of the mobile triboelement on a single actual contact spot (ACS) is calculated by the formula, which is presented in work [15]:

$$
\dot{\varepsilon}_{m}=75 \cdot\left(1+\mu_{m}\right)\left(0,86-1,05 \mu_{m}\right) \frac{\sigma_{A C S} \cdot \mathrm{v}_{S S}}{E_{m} \cdot d_{A C S}}, 1 / \mathrm{s},
$$

for the material of the stationary triboelement:

$$
\dot{\varepsilon}_{s t}=75 \cdot\left(1+\mu_{s t}\right)\left(0,86-1,05 \mu_{s t}\right) \frac{\sigma_{A C S} \cdot v_{s s}}{E_{s t} \cdot d_{A C S}}, 1 / \mathrm{s}
$$

where $\mu_{m}$ and $\mu_{s t}$ - Poisson's ration for the mobile and stationary triboelements;

$\sigma_{A C S}$ - the voltage on the actual contact spot, calculated by the formula presented in work [15], dimension $\mathrm{Pa}$;

$\mathrm{v}_{s s}$ - the slip speed in the tribosystem, $\mathrm{m} / \mathrm{s}$;

$E_{s t}$ and $E_{m}$ - the elastic modulus of the stationary and mobile material of the triboelements, Pa; [15].

$d_{A C S}$ - the diameter of the single actual contact spot, calculated according to the formula given in work

If the construction of the tribosystem (the stationary and mobile triboelement) consists of materials with different elastic moduli $\mathrm{E}$ and Poisson's ratio $\mu$, then expression (1) for determining the information frequency will have the following form:

- for the mobile triboelement:

$$
f_{A E(m)}=n \dot{\varepsilon}_{m}\left(1+\mu_{m}\right)\left(1-2 \mu_{m}\right),
$$

- for the stationary triboelement:

$$
f_{A E(s t)}=n \dot{\varepsilon}_{s t}\left(1+\mu_{s t}\right)\left(1-2 \mu_{s t}\right)
$$

\section{Results}

The experimental studies were carried out on a friction machine according to the kinematic "ring-ring" scheme under the following conditions: the mobile triboelement steel 40X (45 .. 47 HRC), the stationary triboelement Br.AZh 9-4 (90 ... $110 \mathrm{HB})$; grey cast iron SCh (HB 270); steel 40X (45 ... $47 \mathrm{HRC})$. The lubricating medium is engine oil $\mathrm{M}-10 \mathrm{G}_{2 \mathrm{k}}$. The mutual overlap coefficient varied from 0,2 to 0,8 , therefore, the friction area of the stationary triboelement was $F_{\min }=0,00006 \mathrm{~m}^{2} ; 0,00015 \mathrm{~m}^{2} ; 0,00024 \mathrm{~m}^{2}$.

The block diagram of the experimental equipment for recording and processing the AE signals from the friction zone is shown in Fig. 1.

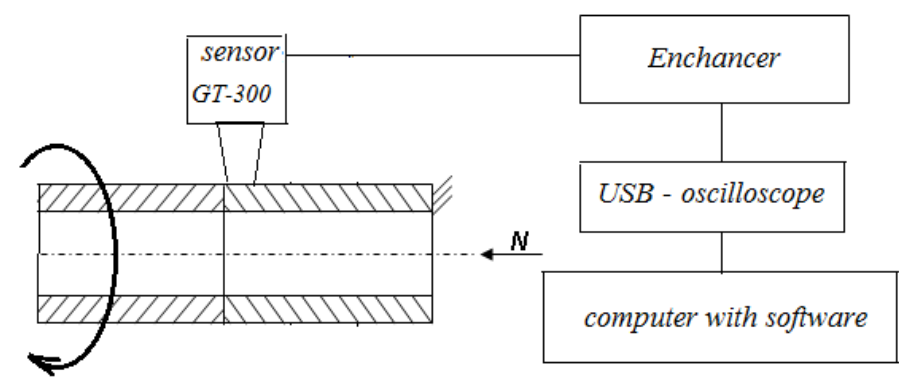

Fig. 1. The block diagram of the experimental equipment for recording and processing the $\mathrm{AE}$ signals from the friction zone

The AE signal from the friction zone is recorded by the GT300 (100 .. $800 \mathrm{kHz})$ broadband sensor, Fig. 1, which was mounted on the stationary triboelement, was transmitted to the amplifier, then, in the analogue form, to the USB oscilloscope PV6501, which performs the functions of the analogue-digital converter and 
spectrum frequency analyser at the same time. After being processed in the USB oscilloscope, the signal in the digital code enters the computer, where it is processed by the special software.

The lower signal pass-band is $50 \mathrm{kHz}$, which does not allow recording signals from the test equipment (the friction machine). The upper pass-band of the signal is 1,5 MHz. Such a frequency range was selected based on the analysis of the works of other authors, which are devoted to acoustic emission from the friction zone [1 - 14].

The pass-band of the USB oscilloscope, Fig. 1, is $20 \mathrm{MHz}$, which is many times greater than the selected working pass-band and signal recording. Thus, with the help of low and high frequency filters, the AEsignal from the friction zone in the range of $50 \ldots 1500 \mathrm{kHz}$ was recorded and analysed in the studies.

The USB oscilloscope is in the standby mode and starts by command for the recording time of 1000 microseconds. This time was selected based on the analysis of the AE signal at the set mode with help of the autocorrelation function.

While checking the homogeneity of the dispersions of the selected AE signal frames at the set mode of operation of the tribosystem, as well as the reproducibility of the results from frame to frame, ISO 5725 standard recommends the use of the Cochrane criterion. The Cochrane criterion allows one to compare the homogeneity of dispersions of the results of the analysis of the AE signals from different frames.

The experimental studies were carried out with the following friction modes: load $N=500 \ldots 1500 \mathrm{~N}$; slip speed $0,2 \ldots 0,8 \mathrm{~m} / \mathrm{s}$. During the experiments, we recorded the information frequencies at which the maximum amplitudes values were observed.

The experimental studies aimed to confirm the correlation between the theoretical (calculated) values of the information frequencies, formulas (5 - 6) and the experimental values with the determination of correlation coefficients. By information frequencies we mean the frequency range where the maximum values of the amplitudes are observed.

The results of the experimental studies are presented in Fig. 2 - 7, which display the average values of the information frequencies at the set mode of operation of the tribosystem (after the completion of running-in) at various loads, as well as the calculated values of frequencies depending on various factors.

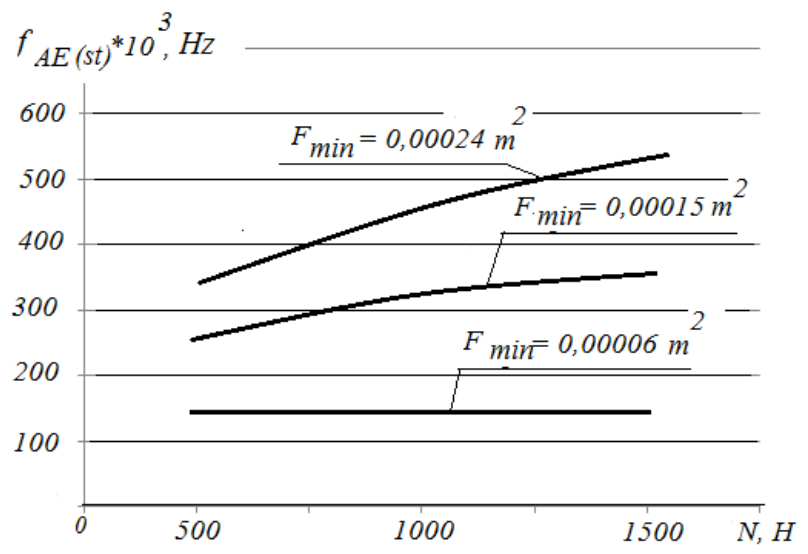

Fig. 2. Change in the $A E$ information frequency of a stationary triboelement $f_{A E(s t)}$ with a change in the friction area $F_{\min }$ at various loads $N$

The dependences of the change in the information frequency of $\mathrm{AE}-f_{A E(s t)}$ for the tribosystem (the mobile triboelement - steel 40X, the stationary triboelement - Br.AZh 9-4), with a change in the friction area $F_{\min }$ at various loads $N$, are presented in Fig. 2. The analysis of the obtained dependences allows us to state about a significant influence of the friction area on the frequency of the generated signal in the tribosystem. For example, with $F_{\min }=0,00006 \mathrm{~m}^{2}$, the mutual overlap coefficient $K_{m o}=0,2$, the information frequency does not change with increasing the load and is $140 \mathrm{kHz}$. With the increase of the area of friction, the information frequency increases. With $K_{m o}=0,5\left(F_{\min }=0,00015 \mathrm{~m}^{2}\right)$, the frequency increases to $365 \mathrm{kHz}$, and with $K_{m o}=0,8$ $\left(F_{\min }=0,00024 \mathrm{~m}^{2}\right)$ the frequency increases to $530 \mathrm{kHz}$.

Based on the results obtained, we can make a conclusion about the significant influence of the constructive factor $\left(F_{\min }\right)$ on the information frequencies generated by the tribosystem during operation.

The dependences of the change in the information frequency for the similar tribosystem with a change in the material of the stationary triboelement, which in formula (4) is determined through the elastic modulus and Poisson's ratio, for various loads N, are presented in Fig. 3. The analysis of the obtained dependences allows us to state that there is an insignificant influence of the elastic modulus and Poisson's ratio of the material on the frequency of the generated signal. The information frequency with increasing the load changes slightly and amounts to: for the tribosystem of steel $40 \mathrm{X}+$ steel $40 \mathrm{X}(244 \ldots 363 \mathrm{kHz})$; for the tribosystem of steel $40 \mathrm{X}+\mathrm{Br} . \mathrm{AZh} 9-4(265 \ldots 365 \mathrm{kHz})$; for the tribosystem of steel 40X + SCh $(284 \ldots 411 \mathrm{kHz})$. 


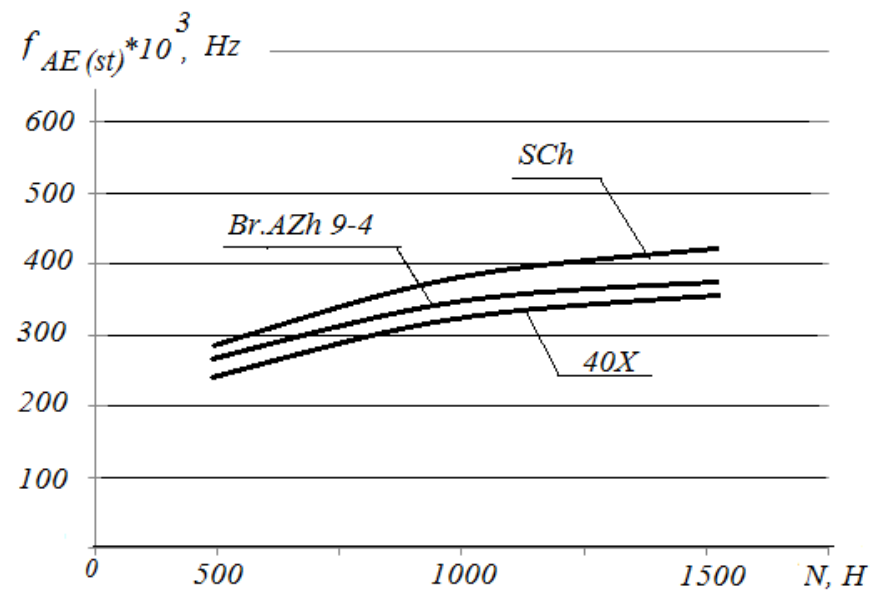

Fig. 3. The change in the information frequency of the $\mathbf{A E}$ of a fixed triboelement $f_{A E(s t)}$ with a change in the material of a fixed triboelement at different loads $N$

The similar dependences were obtained for the information frequencies that the mobile triboelement generates when changing the material of the stationary triboelement, Fig. 4. The information frequency with increasing the load changes slightly and amounts to: for the tribosystem of steel 40X + steel $40 \mathrm{X}(244 \ldots 363 \mathrm{kHz})$; for the tribosystem of steel $40 \mathrm{X}+\mathrm{Br} . \mathrm{AZh} 9-4 \quad(207 \quad \ldots 285 \mathrm{kHz})$; for the tribosystem of steel $40 \mathrm{X}+\mathrm{SCh}(230 \ldots 332 \mathrm{kHz})$.

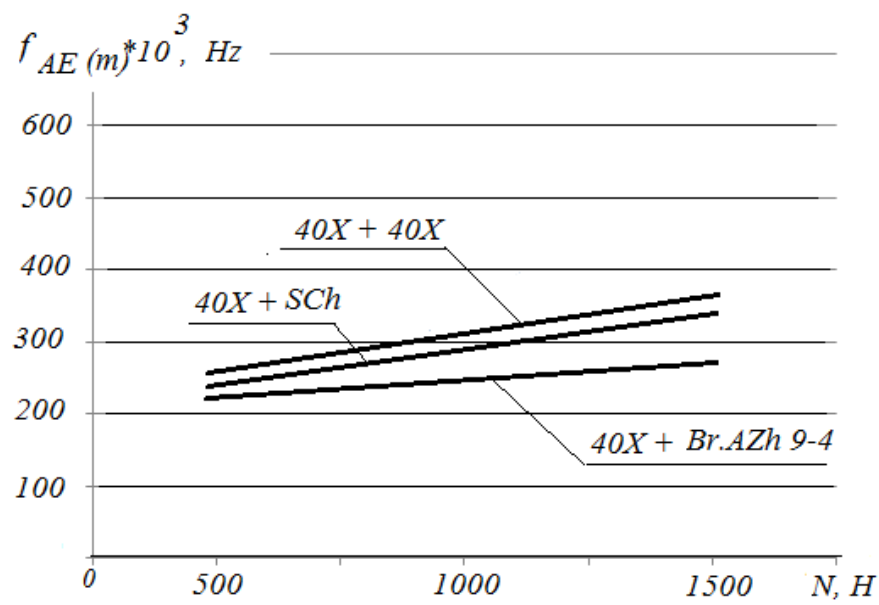

Fig. 4. The change in the information frequency of the $\mathrm{AE}$ of the moving triboelement $f_{A E(m)}$ when changing the material of the stationary triboelement at different loads $N$

Comparing the data obtained by the values of the information frequencies, which are presented in Fig. 3 and 4, it can be concluded that the stationary triboelement with a smaller friction area generates higher frequencies (1,23 ... 1,28 times higher) than the mobile one. This fact must be taken into account when developing methods for diagnosing tribosystems in operation.

The dependences of the change in the information frequency for the tribosystem of steel $40 \mathrm{X}+\mathrm{Br}$. AZh 9 - 4 with a change in the roughness $(R a, S m)$ of the mobile and stationary triboelement, at various loads $N$ on the tribosystem, are presented in Fig. 5 and 6. The analysis of the obtained dependences allows us to state the significant influence of the data of the technological parameters on the information frequency.

An increase in $R a$ leads to a significant increase in the information frequency, for example, at $R a=0,1$ $\mu \mathrm{m} f_{A E(s t)}=168 \ldots 183 \mathrm{kHz}$, and at $R a=0,4 \mu \mathrm{m} f_{A E(s t)}=378 \ldots 618 \mathrm{kHz}$.

The similar dependences were obtained with a change in the average step of roughnesses $\mathrm{Sm}$, Fig. 6. A slight decrease in the step of roughnesses from $S m=0,5 \mathrm{~mm}$ to $S m=0,4 \mathrm{~mm}$ leads to an increase in the information frequency from the values of $f_{A E(s t)}=118 \ldots 152 \mathrm{kHz}$ to the values of $f_{A E(s t)}=265 \ldots 365 \mathrm{kHz}$, i.e. by 2,24 ... 2,4 times. 


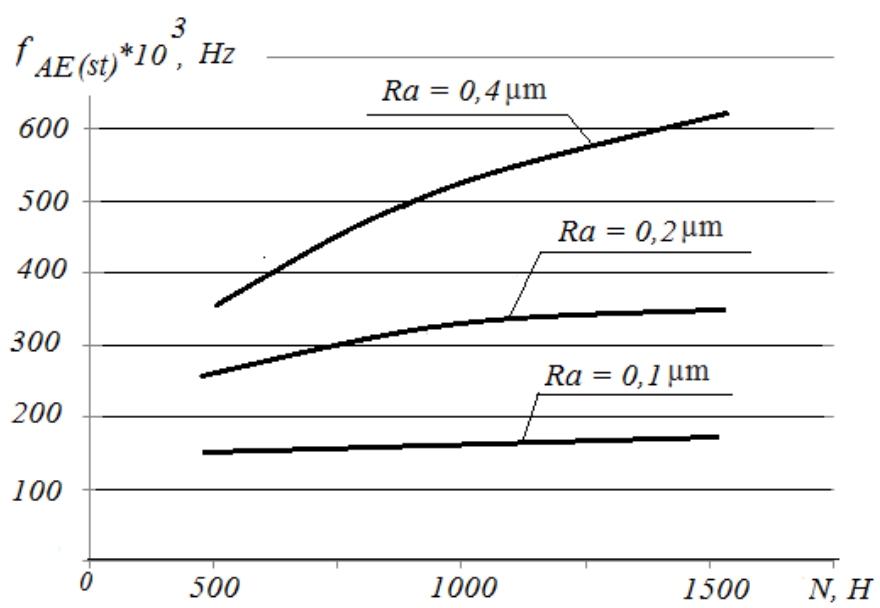

Fig. 5. Change in the information frequency of the $\mathbf{A E}$ of a stationary triboelement $f_{A E(s t)}$ with a change in the roughness $R a$ of the friction surfaces at various loads $N$



Fig. 6. Change in the information frequency of the $A E$ of a fixed triboelement $f_{A E(s t)}$ with a change in the average step of the roughness $\mathrm{Sm}$ of friction surfaces at various loads $N$

Based on the results obtained, we can be make a conclusion about the significant influence of the technological factors $(\mathrm{Ra}, \mathrm{Sm})$ on the information frequencies generated by the tribosystem during operation.



Fig. 7. Change in the information frequency of the $A E$ of a fixed triboelement $f_{A E(s t)}$ with a change in the sliding velocity $v_{s s}$ at various loads $N$ 
The dependences of the change in the $\mathrm{AE}$ information frequency $-f_{A E(s t)}$ for the tribosystem (the mobile triboelement - steel 40X, the stationary triboelement - Br.AZh 9-4), with a change in the slip speed $v_{s s}$ for different loads $N$, are shown in Fig. 7. The analysis of the obtained dependences allows us to assert a significant influence of the slip speed on the frequency of the generated signal in the tribosystem. At $v_{s s}=0,2 \mathrm{~m} / \mathrm{s}$, the information frequency with an increase in the load changes insignificantly and amounts to 106 ... $146 \mathrm{kHz}$. With an increase in the slip speed to $v_{s s}=0,8 \mathrm{~m} / \mathrm{s}$, the information frequency increases to $424 \ldots 584 \mathrm{kHz}$, i.e. by 4 times.

Based on the results obtained, we can be make a conclusion about the significant influence of the operational factors $\left(N, v_{s s}\right)$ on the information frequencies generated by the tribosystem during operation.

The obtained theoretical dependences were tested experimentally with an assessment of adequacy and reproducibility. The results of measuring the AE signals when changing the constructive, technological, and operational factors, followed by the calculation of the Fisher and Cochrane criteria, have showed that the information frequencies of the $\mathrm{AE}$ signals are adequate to the calculated ones, they are homogeneous and reproducible.

The analysis of the obtained dependences allows stating about a correlation between the theoretical values of the information frequencies generated by the tribosystem and the experimental values of the frequencies where the maximum amplitudes were recorded, the correlation coefficient $r=0,88$.

Analysing the presented dependences in Fig. 2 - 7, it is possible to make a conclusion that the choice of the information frequencies of the acoustic emission signals, taking into account the constructive, technological and operational factors, will allow increasing the robustness and information content of the AE method. The present analysis can be the basis for the development of the method for diagnosing tribosystems during their operation.

\section{Conclusions}

Based on the performed analysis of the works devoted to the selection of the informative parameters of $\mathrm{AE}$ for the diagnosis of tribosystems, with help of a theoretical way we have established the information frequency ranges in the frame of the AE signal, where maximum amplitudes values are observed. It has been theoretically and experimentally established that the information frequencies depend on the following groups of factors: the constructive; technological and operational ones. The degree of influence of factors on the change in the frequency range has been established. The operational factors (slip speed and load) change the frequency range from 106 to $584 \mathrm{kHz}$, the technological factors (roughness of the friction surfaces) change the frequency range from 118 to $618 \mathrm{kHz}$, the constructive factors (the size of the friction area of the stationary triboelement) change the frequency range from 140 to $530 \mathrm{kHz}$. This suggests that for the effective diagnosis of tribosystems, it is necessary to determine the information frequency range in advance, taking into account the factors listed above.

The results were confirmed experimentally with the calculation of the Fisher and Cochrane criteria, which allows us to confirm the presence of a correlation between the theoretical values of the information frequencies generated by the tribosystem, and the experimental value of the frequencies, where the maximum amplitudes were recorded, the correlation coefficient $r=0,88$.

The present analysis can be the basis for the development of a diagnostic method for tribosystems during their operation, which will allow increasing the robustness and information content of the AE method.

\section{References}

1. Sviridenok, A.I. Akusticheskiye i elektricheskiye metody v tribotekhnike / A.I. Sviridenok [i dr.] ; pod red. V.A. Belogo. - Minsk : Nauka i tekhnika, 1987. - 280 s. [Russian]

2. Shchavelin, V.M., Sarychev G.A. Akusticheskiy kontrol' uzlov treniya YAEU.- M. : Energoatomizdat, 1988. - 176 s. [Russian]

3. Potekayev, A.I., Plotnikov V.A. Akusticheskaya dissipatsiya energii pri termouprugikh martensitnykh prevrashcheniyakh. - Tomsk: Izd-vo NTL, 2004. - 196 s. [Russian]

4. Makarov, S.V., Plotnikov V.A., Potekayev A.I. Vysokotemperaturnaya plasticheskaya deformatsiya i akusticheskaya emissiya alyuminiya v slaboustoychivom sostoyanii / Izvestiya vuzov. Fizika. - 2013. - T. 56. №6. - S. 23-30. [Russian]

5. Baranov A.V., Vagner V.A., Barsukov G.V. Diagnostika raboty par treniya / Polzunovskiy vestnik, 2005, №2(ch.2), s. 149-152. [Russian]

6. Kolubayev Ye.A., Rubtsov V.Ye., Kolubayev A.V. Osobennosti izlucheniya akusticheskogo signala pri sukhom trenii skol'zheniya / Obrabotka metallov. Issledovaniya po FTSP, 2013, №1(58), s.69-74. [Russian]

7. Vinogradov A., Lazarev A., Linderov M., Weidner A., Biermann H. Kinetics of deformation processes in high-alloyed cast transformation-induced plasticity/twinning-induced plasticity steels determined by acoustic emission and scanning electron microscopy: Influence of austenite stability on deformation mechanisms / Acta Materialia, 2013, Vol. 61, №7. P. 2434-2449. [English] 
8. Linderov M., Segel C., Weidner A., Biermann H., Vinogradov A. Deformation mechanisms in austenitic TRIP/TWIP steels at room and elevated temperature investigated by acoustic emission and scanning electron microscopy / Materials Science and Engineering: A. 2014, Vol. 597. P. 183-193. [English]

9. Müller A., Segel C., Linderov M., Vinogradov A., Weidner A., Biermann H. The Portevin-Le Châtelier effect in a metastable austenitic stain-less steel / Metallurgical and Materials Transactions A. 2016. Vol. 47. №1. P. 59-74. [English]

10. Makarov, S.V., Plotnikov V.A., Kolubayev Ye.A. Deformatsionnoye povedeniye alyuminiyevomagniyevogo splava v usloviyakh termomekhanicheskogo nagruzheniya / Izvestiya AltGU. - 2015. - № 2. - S. 36-39. [Russian]

11. Makarov, S.V., Plotnikov V.A., Lysikov M.V. i dr. Nakopleniye deformatsii i akusticheskaya emissiya $\mathrm{v}$ usloviyakh termomekhanicheskogo nagruzheniya alyuminiyevo-magniyevogo splava / Izvestiya AltGU. 2015, № 2. S. 40-44. [Russian]

12. Makarov, S.V., Plotnikov V.A., Lysikov M.V. et al. Acoustic emission and effect of stepwise deformation in aluminum-magnesium alloy / Advanced Materials with Hierarchical Structure for New Technologies and Reliable Structures AIP Conf. Proc. 2015. 1683, 020138-1-020138-5. [English]

13. Makarov, S.V., Plotnikov V.A., Kolubayev Ye.A. Zakonomernosti akusticheskoy emissii v usloviyakh plasticheskoy deformatsii alyuminiyevo-magniyevogo splava pri neizotermicheskom nagruzhenii / Iz-vestiya AltGU. 2014. № 1. S. 252-256. [Russian]

14. Makarov, S.V., Lysikov M.V., Kolubaev E.A. et al. The deformation and acoustic emission of aluminum-magnesium alloy under non-isothermal thermo-mechanical loading / Advanced Materials with Hierarchical Structure for New Technologies and Reliable Structures AIP Conf. Proc. 2015. 1683, 020139-1020139- 5. [English]

15. Voytov V.A., Zakharchenko M.B. Modelirovaniye protsessov treniya iznashivaniya v tribosistemakh v usloviyakh granichnoy smazki. Chast' 1. Raschet skorosti raboty dissipatsii v tribosistemakh / Problemi tribologíi. - 2015. - № 1. - S. 49-57. [Russian]

Фененко К.А. Визначення інформаційних частот в фреймі сигналів акустичної емісії із зони тертя трибосистем.

На підставі виконаного аналізу робіт, присвячених вибору інформативних параметрів АЕ для діагностування трибосистем, теоретичним шляхом встановлено інформаційні частотні смуги в фреймі сигналу АЕ, де спостерігаються максимальні значення амплітуд. Теоретично і експериментально встановлено, що інформаційні частоти залежать від наступних груп факторів: конструктивних; технологічних і експлуатаційних. Встановлено ступінь впливу факторів на зміну частотного діапазону. Експлуатаційні фактори (швидкість ковзання і навантаження) змінюють діапазон частот від 106 до 584 кГц, технологічні фактори (шорсткість поверхонь тертя) змінюють діапазон частот від 118 до 618 кГц, конструктивні фактори (величина площі тертя нерухомого трибоелемента) змінюють діапазон частот від 140 до 530 кГц. Зроблено висновок, що для ефективного діагностування трибосистем необхідно попередньо визначати інформаційний частотний діапазон з урахуванням перерахованих вище факторів.

Отримані результати були підтверджені експериментально з розрахунком критеріїв Фішера i Кохрена, що дозволяє стверджувати про наявність кореляційного зв'язку між теоретичними значеннями інформаційних частот, що генеруються трибосистеми і експериментальними значеннями частот, де реєструвалися максимальні амплітуди, коефіцієнт кореляції $r=0,88$.

Даний аналіз може бути основою для розробки методики діагностування трибосистем під час їх експлуатації, що дозволить підвищити робастність і інформативність методу АЕ.

Ключові слова: трибосистема; інформаційні частоти; акустична емісія; частотний діапазон; диагностування; конструктивні, технологічні, експлуатаційні фактори. 